\title{
USING EXTENSIVE READING TO IMPROVE ECONOMIC VOCABULARY FOR SECOND-YEAR STUDENTS AT THE UNIVERSITY OF LANGUAGES AND INTERNATIONAL STUDIES - VIETNAM NATIONAL UNIVERSITY, HANOI
}

\author{
Truong Thi Phuong* \\ Department of Language Training and Professional Development, VNU University of Languages \\ and International Studies, Pham Van Dong, Cau Giay, Hanoi, Vietnam
}

Received 05 June 2018

Revised 28 July 2018; Accepted 31 July 2018

\begin{abstract}
There are different ways to improve vocabulary knowledge and one of them is through extensive reading. This paper aims to identify benefits of extensive reading on some aspects of vocabulary learning and ways to conduct a successful extensive reading program. In order to answer the two research questions, the researcher collected and analyzed online journal articles which focus on the relationship between vocabulary development and extensive reading. The results show that extensive reading not only improves new vocabulary knowledge but also fosters previously met words. Moreover, some specific aspects of vocabulary learning are benefited thanks to extensive reading such as meaning, spelling and grammar. Finally, some recommendations on how to carry out an extensive reading are raised at the end of the result section based on various researchers' opinions.
\end{abstract}

Keywords: vocabulary acquisition, extensive reading, language learning

\section{Introduction}

It cannot be denied that to master a language, learners not only have to be fluent in all four skills including speaking, listening, reading and writing but also take vocabulary learning into consideration. According to $\mathrm{Xu}$ (2010), vocabulary learning is crucial in the process of foreign language learning. It is a great challenge and enormous duty for learners as well as teachers. Admitting that vocabulary is remarkably important, Wilkins (1974, as cited in $\mathrm{Xu}, 2010$ ) claimed that people cannot communicate without vocabulary.

Regarding vocabulary learning, some researchers mentioned "extensive reading" as a useful method. In 1993, Stoller and Grabe raised an idea that vocabulary improvement

\footnotetext{
${ }^{*}$ Tel.: 84-973625003
}

Email: truongthiphuong.hulis@gmail.com should be considered both cause and effect of reading proficiency. Sharing the relatively similar ideas, Day (2002) concluded that apart from benefits on motivation and attitude towards reading, extensive reading can help develop learners' vocabulary. There have been a number of studies on reading and vocabulary improvement such as Learning Second Language Vocabulary from Extensive Reading (Horst, 2005), Vocabulary Acquisition from Extensive Reading (Pigada \& Schmitt, 2006) or Extensive Reading - a Stimulant to Improve Vocabulary Knowledge (Soltani, 2011). All these researchers admitted benefits that extensive reading brings to learners on vocabulary acquisition.

However, two substantial questions related to this issue are raised as to how extensive reading can improve vocabulary knowledge and how an extensive reading 
program should be conducted to foster its benefits. Recognizing the importance of the relationship between extensive reading and vocabulary acquisition, the researcher decided to conduct a secondary research on this topic and aimed to answer the two above-mentioned questions. Afterwards, some recommendations are also raised to help second-year students at the University of Languages and International Studies to improve their economic vocabulary after an extensive reading program. Economic vocabulary is really important in Vietnamese current context because economy-related jobs are plentiful and to have a good job, English fluency including economic vocabulary is essential.

\section{Research questions}

The paper aims to answer two questions:

1. How can extensive reading help improve vocabulary knowledge?

2. How should an extensive reading program be conducted to foster its benefits?

\section{Literature review}

\subsection{Vocabulary knowledge}

In the research process, a number of definitions of vocabulary knowledge and extensive reading have been found. In 2000, Blachowicz and Fisher considered vocabulary knowledge a clue of "power and wisdom" because it helps people to convey and exchange ideas as well as understand others both in speaking and writing. As for vocabulary acquisition, Ellis (1995) raised two alternative hypotheses including implicit and explicit vocabulary learning. $\mathrm{He}$ distinguished these hypotheses by stating that implicit vocabulary learning process takes place when learners subconsciously acquire the meaning of the words through "repeated exposures" in different contexts. It means that, in this case, learners totally do not recognize the acquisition process. In explicit vocabulary learning, on the contrary, learners acquire new words by applying various "metacognitive strategies" such as (1) identifying unfamiliar words, (2) attempting to infer the meaning based on the context or look up the word in dictionaries, (3) trying to remember the word by repetition or learning strategies.

\subsection{Extensive reading}

Regarding extensive reading, in 1989, Hafiz and Tudor (1989: 85) stated extensive reading is reading a large amount of second language material for pleasure without any task or exercise fulfillment. From the similar point of view, Grabe and Stoller (2002) considered extensive reading "an approach to the teaching and learning of reading in which learners read large quantities of material that is within their linguistic competence". This definition is somehow different from Krashen's ideas (1982) when he supposed that the difficulty level of materials in an extensive reading should be higher than learner's current reading level. Additionally, Rodrigo et al. (2007) defined extensive reading as reading in a huge amount to thoroughly understand the text or to enjoy the reading experience. All these definitions share the same idea that extensive reading involves reading a large quantity of second language materials, reading for interest and enjoyment.

\section{Methodology}

As this is a secondary research, the author focuses on collecting and then analyzing journal articles related to the topic. Besides, online journal articles are chosen as the main references. Most of the articles are taken from online journals specialized in English Language Teaching, English as a Second Language or English as a Foreign 
Language. The main sources are The English Teacher, Reading in a Foreign Language and The Reading Matrix. The collected articles are studies conducted in various learning contexts and countries such as China and Japan. The participants of those studies are also mostly college students and adult learners.

The methodology which is chosen for this paper is qualitative research. There are some reasons for conducting a qualitative research, but not a quantitative one. According to Nagy \& Leavy (2011), this kind of methodology is suitable for a small-scale context. Besides, qualitative research uses "inductive" method starting with specific data which will be analyzed to a more general understanding of the topic or the field. Research questions in qualitative studies are open-ended questions and they offer explanations and descriptions in the report papers. For all of the above reasons, qualitative methodology is suitable for this research paper. The study focuses on analyzing six main journal articles; therefore, it is really small-scale. Research questions are also openended ones and the researcher aims to seeking more general understanding of benefits of extensive reading on vocabulary acquisition.

Regarding participants, the article "Vocabulary Acquisition from Extensive Reading: A Case Study" only focused on a 27-year-old student (Pigada \& Schmitt, 2006). Meanwhile, there were 43 adult literacy students participating in "Implementing an Extensive Reading Program and Library for Adult Literacy Learners" (Rodgrigo et al, 2007). Another study, "Bridging the Gap between Receptive and Productive Vocabulary Size through Extensive Reading" involved 67 students from one co-educational class at a private university in Tokyo, Japan (Yamamoto, 2011). The other studies are just analysis and synthesis of theoretical background.

\section{Results}

This part aims to find out the answer for the two research questions. After reading some articles related to the topic "Role of Extensive Reading in Vocabulary Development", the researcher realized that most of the studies had figured out some certain benefits of extensive reading on vocabulary acquisition. Then, the researcher analyzed the similarities and the differences in their ideas and reported below.

\subsection{Benefits of extensive reading on vocabulary acquisition}

Benefits of extensive reading on vocabulary acquisition have been mentioned by a number of researchers. Based on Lee and Mallinder (2017), extensive reading particularly benefits incidental vocabulary acquisition. He cited two studies to prove this argument. In Min's paper, there were 12-grade students who participated in a reading-plusvocabulary-enhancement program. After the program, these participants improved 50 items of vocabulary. Likewise, 38 participating college students were capable of gaining $10.5 \%$ new words after reading 16 articles.

Also in their research, Lee \& Mallinder (2017) pointed out some of extensive reading features which contribute to bring along benefits on EFL vocabulary development. They are:

\section{Variety}

Whereas daily communication mostly take advantage of 2000 basic words (Schmitt, 2000), extensive reading provides language learners opportunity to expose to variety of vocabulary which may not occur in spoken language.

\section{Repetition}

Clearly, repeated exposure to a word in different reading contexts will increase the chance for learners to acquire that word. Thus, 
learners are able to strengthen their recently acquired knowledge thanks to extensive reading.

\section{Flexibility}

It is the truth that teachers do not have enough time to teach every new word. In an extensive program, after school, learners can continue to read and enjoy their reading experience. They, consequently, will become more independent and responsible for their vocabulary learning.

Another aspect of extensive reading benefits is also paid attention by Yamamoto (2011). Meanwhile many other studies focus on learning new vocabulary as an outstanding feature of extensive reading, Yamamoto (2011) mentioned benefits of extensive reading on improving previously met vocabulary. This researcher affirmed that language learners can deepen their knowledge of already acquired words by exposing to the words repeatedly. Nation (2001) thought that extensive reading is a "gradual process of one meeting with a word adding to or strengthening the small amounts of knowledge gained from previous meetings".

From another point of view, Pigada and Schmitt(2006)mentioned benefits of extensive reading on some aspects of vocabulary knowledge such as spelling, meaning and grammar characteristics. Specifically, the results of their research showed that there was a strong improvement in word spelling. In the pre-test, the participant only got 98 points out of 266; however, the mark came to 159 out of 266 in the post-test. Besides, meaning aspect also got improvement. The mark the participant got in the pre-test and post-test were 22 and 63 out of 266 respectively. The last aspect which was taken notice in the research is grammatical characteristics. After conducting the study, the authors concluded the participant improved quite a lot in grammatical mastery of nouns (for example knowledge of appropriate articles). The results presented the language learner who took part in the questionnaire got 18 out of 140 for the pre-test, compared with 60 in the post-test. Overall, it can be concluded that knowledge of word spelling was benefited most by extensive reading. Knowledge of meaning and grammatical features is also improved but at a lower extent.

\subsection{Implementing an extensive reading program}

To answer the question how an effective extensive reading can be implemented, Day and Bamford (2002) raised an idea of Top Ten Principles for Teaching Extensive Reading. These principles are believed to be the basic ingredients of extensive reading. In their opinion, not only does extensive reading have huge impact on reading and language ability, but it is also "a key to unlocking the allimportant taste for foreign language reading among students" (Eskey, 1995, as cited in Day \& Bamford, 2002).

\section{The reading material is easy}

This principle relates to the number of "new words" in a text. In order to have an effective extensive reading program, the selected reading texts must be beyond the learners' language competence. To be specific, for beginner students, the materials which are considered beyond their ability must contain no more than one or two unknown words per page. The learners at intermediate level can deal with the texts with no more than five difficult words per page. $\mathrm{Hu}$ and Nation (2000) suggest that in order to have thorough understanding of a fiction text, the learners must know at least $98 \%$ of the words.

$A$ variety of reading material on a wide range of topics must be available 
To have a successful extensive reading program, the teachers must know how to motivate and attract the learners to read. This depends a lot on the variety of the texts. Specifically, the reading text should be as varied as the learners who read them and the purposes for which they read them. Some kinds of the text include books, magazines, newspaper, fiction, nonfiction, texts that inform or texts that entertain. According to William (1982: 42) in order to choose a suitable reading source, the teachers should "ask what they like reading in their own language, peer over their shoulders in the library and ask the school librarian".

\section{Learners choose what they want to read}

This principle means that in extensive reading programs, learners are free to choose their reading texts as they do in their own language. They can choose the texts that meet their level to have the best understanding and similarly, they can decide to stop reading if they find the texts too difficult or out of their interest.

In Henry's opinion (1995), “My students needed to read for them, not for me". Especially, for the students who are familiar with textbooks and teacher-selected texts, the freedom to choose reading materials and to stop reading will helps them think that foreign language reading is something personal.

Moreover, although there may be homework, extensive reading puts the students in charge in other important ways. Also in his research, Henry affirmed that "the purposes and pleasure to which students put their reading are entirely their own" (p.69). This will motivate the students and help them become more responsible for their reading. Sharing this opinion, Samuels (1991, as cited in Day and Bamford, 2002) claimed that "unless we phase out the teacher and phase in the learner, many of our students will fail to become independent because throughout their education they were always placed in a dependent role -- dependent on the teacher".

\section{Learners read as much as possible}

This is the most crucial element in extensive reading which a lot of teachers agree with. There is only one problem, which is the students are not being given the opportunity or incentive to read, read and read more.

There is no maximum limit for the amount of time students should spend on reading, but they are expected to finish a book in a week. That is the minimum speed which can help them achieve the benefits of extensive reading and set up a reading habit. This is realistic for the learners at all level because the books written for beginners are often rather short.

\section{Reading is its own reward}

The main focus of extensive reading approach is the learners' experience when they read the texts, just as it is in reading in everyday life. Therefore, extensive reading does not normally go with comprehension exercises. Instead, it is the teacher's duty to check the students' comprehension through follow-up activities. There are some reasons for this. First, the teachers can be sure what the students understood and experienced from reading thanks to those follow-up activities. Second, the students' attitude towards reading can be monitored. Apart from that, the teacher can also keep track of what and how much students read, make reading a shared experience, link reading to other aspects of the curriculum. Therefore, after reading, the students may be asked to do such things as write about their favorite characters, write about the best or worst book they have read, or do a dramatic reading of an exciting part of a novel. 
Reading speed is usually faster rather than slower

When learners deal with the texts within their level, for personal interest, for general understanding, they will focus on reading fluency. Nuttall notes that "speed, enjoyment and comprehension are closely linked with one another" (1996, as cited in Day and Bamford, 2002). She describes "The vicious circle of the weak reader: Reads slowly; Doesn't enjoy reading; Doesn't read much; Doesn't understand; Reads slowly". Extensive reading can help readers "enter instead the cycle of growth. The virtuous circle of the good reader: Reads faster; Reads more; Understands better; Enjoys reading; Reads faster" (p.127).

The teachers also encourage their students not to use dictionaries in reading. In extensive reading, they can experience some skills like guessing the meaning of the words, ignoring the new words or simple accepting ambiguity in reading.

\section{Reading is individual and silent}

Different from classroom reading in which the students may be asked to read aloud or translate the text into their own language to practice reading skills and strategies, extensive reading is individual and silent. The students have chance to experience reading and interact with the text. Therefore, apart from freedom to choose the reading materials, individual silent reading is also a crucial element in extensive reading approach which helps the students discover how foreign language reading fit into their lives.

Extensive reading means learners reading at their own pace. It can be done both in the students' own time when and where the student chooses, or inside the classroom when part or all of a classroom period is set aside for silent, self-selected reading. In the latter case, teachers may witness.
Teachers orient and guide their students

Extensive reading can be very different from normal reading practice in class. Normally, in reading sections the students have to deal with difficult texts, answer series of questions. However, in this approach, the texts are much easier and they hardly have reading comprehension exercises. For serious learners, they may not understand the purpose of this approach.

Consequently, the students need to have thorough introduction and guide from the teachers at the very beginning of the program. Teachers can explain that reading extensively leads not only to gains in reading proficiency but also to overall gains in language learning. Some other details of the program also need to be introduced, for example students' choosing texts or percentage of understanding (general, less than $100 \%$ ). It should be emphasized that there will be no test after reading. Instead, teachers are interested in the student's own personal experience of what was read -- for example, was it enjoyable or interesting, and why?

\section{The teacher is a role model of a reader}

There are a lot of researchers who have the same ideas in this principle. Nuttall famously said "Reading is caught, not taught" (1996: 229). Maley explains the implications of this for teachers when he said "We need to realize how much influence we have on our students. Students do not just (or even) learn the subject matter we teach them; they learn their teachers. Teacher attitude, more than technical expertise, is what they will recall when they leave us" (1999: 7). In short, to have successful extensive reading program, the teachers are readers themselves.

In Henry's opinion (p. 52), teachers of extensive reading "have to commit to reading what their students do". He explains that when reading the texts that students read, the 
teachers will become a part of the reading community. Besides, if both the teachers and the students read, the classroom will become a place where they can share about reading experience, discuss about the books or answer questions related to reading.

Sharing the same concern with Day \& Bamford, Lee \& Mallinder (2017) pointed out some essential criteria for successful extensive reading. In their opinion, to conduct an effective extensive reading program, teachers have to take notice of the period of time, the number of reading texts and the appropriateness of materials. To be detailed, interesting comprehensible materials are the key to the success of this kind of program. The materials chosen should be:

- Readable: Reading materials should not be too long and should be with learner's reading competence.

- Appropriate and authentic: The reason given is that each learner's own background knowledge can affect the reading process; therefore, the texts should be authentic and familiar in terms of culture.

- Attractive and various: The materials should cover a range of topics and should be attractive to the students. Once they are interested in reading, they will read more as well as apply more reading strategies into reading comprehension.

Apart from the criteria for choosing reading texts, some recommendations are made to facilitate extensive reading program.

\section{Family literacy}

This means that parents should play as a model of reading so that children are encouraged to read more at home. For native English-speaking students, family literacy plays a remarkable important in their language proficiency development and academic success.
A number of studies have proved that these kinds of students have overall better language competence and are more academically successful than other students whose parents do not read to them frequently. Moreover, with English language learners, family literacy activities at home can provide supplementary practices, apart from learning at school.

\section{Introductory workshop}

An introductory workshop is advised to be conducted on the first day of the program. The main purpose is to let students understand the strength as well as advantages extensive reading can have on vocabulary learning. Also, teachers should explain how they are going to include extensive reading into the regular syllabus. Any requirements related to selected texts should be raised in the workshop.

\section{Supportive learning environment}

In the workshop, or at any time before starting the program, teachers should provide learners with essential reading strategies. Some other familiar skills should be also introduced such as consulting a dictionary. Teachers; moreover, may need consider creating a collaborative learning environment in students' extensive reading.

\section{Internet resources}

Teachers should direct students to various websites and advise learners to take advantage of these sources. Teachers, along with learners, can build up an online library with a number of e-books, stories, novels or even magazines and newspapers. With Internet, both teachers and students and enjoy free extensive reading. Because of easy access to Internet, students can decide what, when and how long to read.

Focusing on adult learners, Rodrigo et al. (2007) mentioned four components of the Extensive Reading for Adult Literacy Learners. 


\section{Sustained silent reading}

This component means that teachers and learners read their chosen books silently. During the reading process, teachers can help students choose books, answer their questions and observe their reaction; but their conversations must not interfere others' students' silent reading.

\section{Book talk}

Sharing opinion about a book with others will encourage students' curiosity. They will have a chance to exchange ideas and know some more books. This activity can be conducted after each sustained silent reading session.

\section{Reading aloud}

This component is one of the keys to promote an extensive reading program. It provides learners opportunity to expose to unfamiliar books or stories that they do not ordinarily read. It also helps build the connection between sounds and writing symbols. Teachers carry out this activity by choosing a book which students may not read easily by themselves to read aloud to them while they follow silently with their copies.

\section{Students' reaction}

After the first reading-aloud session in which teachers choose reading materials on their own, learners should be asked for input for the next reading-aloud session. This will help teachers choose interesting and appropriate reading texts to the learners.

\section{Conclusion}

For the first research question about benefits of extensive reading on vocabulary acquisition, reasons why extensive reading helps improve vocabulary learning are raised including its variety, repetition and flexibility features. Besides, the result of the research shows that not only new vocabulary but also previously met words are required through reading process. This somehow changes some researchers' point of view towards extensive reading while many of them frequently focus on new vocabulary acquisition. Regarding how extensive reading benefits vocabulary learning's aspects, this study indicates that spelling, meaning and grammatical characteristics are improved thanks to extra reading but to different extents. Specifically, spelling is gained most; meanwhile, meaning and grammatical features are also improved at a lower level.

The second research question concerning how an extensive reading should be implemented, some recommendations are found. Features that teachers need to consider include duration of time, number of reading materials and appropriateness of materials. Some other recommendations are also given to have an effective extensive reading program. To be detailed, teachers should conduct an introductory workshop, create a supportive learning environment and take advantage of Internet resources. However, it is quite strange that creating a supportive learning environment does not mean that teachers let students read and share reading experience together or teachers help students when they encounter difficulties. "Supportive" here means teachers supply their learners with necessary reading strategies at the beginning of the program so that they can read by themselves. Last but not least, four components of an extensive reading program are pointed out including sustained silent reading, book talk, read aloud and students' reaction.

Based on the theoretical background discussed above, the writer recommends designing an extensive reading program for second-year students at University of Languages and International Studies to improve economic vocabulary. The program follows the principles which Day and Bamford (2002) and Lee \& Mallinder (2017) raised in their studies. 
The extensive reading program should last in 3 months. Once a week, each student is asked to read a financial report. According to Day and Bamford (2002), in an extensive reading program, learners should choose what they want to read. Consequently, the students should be required to find reports by themselves. However, these authors also concluded that the reading material must be easy; therefore, there are some requirements for the materials chosen. First, the reports should be no more than two thirds of a page and the number of new words should be no more than 10 .

After reading the text, the students have to note the new words in a vocabulary learning form to learn these words (the form is taken from Barron's 600 essential words for the TOEIC). In this form, there are five columns including new word, synonym, definition, original sentence and my sentence. These notes will be submitted to the teacher in the next lesson.

Subsequently, in the next lesson, a fifteenminute activity should be conducted on this reading. In the activity, the students will be asked to work in groups of four or five and share their reports to the others. When sharing the information, they can take notes if they want. After five to seven minutes, the teacher asks some students from some groups to come to the board and present a piece of news they like most in the group. The piece must not be theirs, but the others'. The purpose of this step is to let the students have a chance to explain their news to the others and make sure that the group understand their explanation. Questions can be raised after each presentation.

\section{References}

Blachowicz, C. \& Fisher, P. J. (2006). Teaching vocabulary in all classrooms. Upper Saddle River, NJ: Pearson/Merrill Prentice Hall.
Day, R. \& Bamford, J. (2002). The Benefits of Extensive Reading (ER). Retrieved June 14 from http://www. google.com.vn/url?sa $=$ t\&rct $=\mathrm{j} \& \mathrm{q}=\&$ esrc $=$ s\&source $=$ web $\& \mathrm{~cd}=1 \& \mathrm{cad}=\mathrm{rja} \& \mathrm{ved}=0 \mathrm{CCoQFjAA} \& u r l=$ http $\% 3 \mathrm{~A} \% 2 \mathrm{~F} \% 2 \mathrm{Fwww}$.oup-bookworms.com $\% 2 \mathrm{Fdown}$

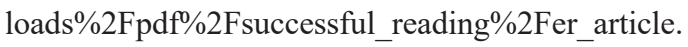
pdf\&ei=5-i6UafWKoeTigfO44HQCw\&usg=AFQjC NF0pZMAg5HKo1GrX8puBWBK2iaKoQ\&sig2=1J pyoc1IZG8InTks0VoRdA\&bvm=bv.47883778,d.aGc

Grabe, W. \& F. Stoller. (2002). Teaching and researching reading. New York: Pearson Education.

Hafiz, F.M. \& Tudor, I. (1989). Extensive reading and the development of language skills. ELT Journal, 34(1), 5-13.

Henry, J. (1995). If not now: Developmental readers in the college classroom. Portsmouth, NH: Boynton/ Cook, Heinemann.

Horst, M. (2005). Learning L2 Vocabulary through Extensive Reading: A Measurement Study. The Canadian Modern Language Review, 61(3), 355382.

Hu, M. \& Nation, P. (2000). Unknown vocabulary density and reading comprehension. Reading in a Foreign Language, 13(1), 403-430.

Krashen, S. (1988). Do we learn to read by reading? The relationship between free reading and reading ability. In D. Tannen (Ed.) Linguistics in Context (pp. 269-298). Norwood, NJ: Ablex

Lee, H. \& Mallinder, M. (2017). Role of Extensive Reading in EFL Vocabulary Development: Review and Recommendation. The English Teacher, XL, 145-163.

Maley, A. (1999). Surviving the 20th century. English Teaching Professional, 10, 3-7.

Min, H.T. (2008). EFL vocabulary acquisition and retention: reading plus vocabulary enhancement activities and narrow reading. Language Learning, 58(1), 73-115.

Nagy, S. \& Leavy, P. (2011). The Practice of Qualitative Research. Boston: SAGE Publications, Inc. Retrieved June $14^{\text {th }}$ from http://www.sagepub. com/upm-data/34087_Chapter1.pdf. 
Nation, I. S. P. (2001). Learning vocabulary in another language. Cambridge, UK: Cambridge University Press.

Nuttall, C. (1996). Teaching reading skills in a foreign language (2nd ed.). Oxford: Heinemann.

Pigada, M., \& Schmitt, N. (2006). Vocabulary Acquisition from Extensive Reading: A Case Study. Reading in a Foreign Language, 18(1), 1-28.

Silva, J. (2006). Extensive Reading through the Internet: Is it Worth the While? The Reading Matrix, 6(1), 85-96.

Soltani, R. (2011). Extensive Reading A Stimulant to Improve Vocabulary Knowledge. Studies in Literature and Language, 2(3), 161-167.

Stoller, F., \& Grabe, W. (1993). Implications for L2 vocabulary acquisition and insturciton from L1 vocabulary research. In T. Huckin, M. Haynes, \& J. Coady (Eds.), Second language reading and vocabulary learning (pp. 24-45). Norwood, NJ: Ablex Pub. Corp.

$\mathrm{Xu}, \mathrm{X}$. (2010). The Effects of Glosses on Incidental Vocabulary Acquisition in Reading. Journal of Language Teaching and Research, 1(2), 117-120.

Rodgrigo, V. et al (2007). Implementing an Extensive Reading Program and Library for Adult Literacy Learners. Reading in a Foreign Language, 19(2), 106-119.

Williams, R. (1986). “Top ten” principles for teaching reading. ELT Journal, 40(1), 42-45.

Yamamoto, Y. (2011). Bridging the Gap between Receptive and Productive Vocabulary Size through Extensive Reading. The Reading Matrix, 11(2), 226-242.

\title{
SỬ DUNG PHƯƠNG THỨC ĐOC MỞ RÔNG ĐỂ NÂNG CAÖ VỐN TƯ VƯNG VỀ KINH TẾ CHO SINH VIÊN NĂM THÚ HAI', TRƯ ỜNG ĐAII HOC NGOẠI NGŨ - ĐẠI HỌC QUỐC ĠIA Hì̀ NộI
}

\author{
Trương Thị Phượng \\ Khoa Đào tạo và Bồi duõng Ngoại ngũu, Truờng Đại học Ngoại ngũ, ĐHQGHN, \\ Phạm Văn Đồng, Cầu Giấy, Hà Nội, Việt Nam
}

Tóm tắt: Có nhiều cách khác nhau có thể áp dụng để nâng cao vốn từ vựng cho người học, một trong những cách đó là phương thức "đọc mở rộng". Bài báo này được thực hiện với mục đích tìm ra lợi ích của “đọc mở rộng” đối với việc học từ vựng và những quy tắc để thiết kế một chương trình đọc mở rộng hiệu quả. Để trả lời hai câu hỏi nghiên cứu trong bài báo này, tác giả đã thu thập và phân tích các bài báo chuyên ngành tập trung vào mối quan hệ của đọc mở rộng và học từ vựng. Kết quả cho thấy rằng, đọc mở rộng không những giúp người học biết được từ mới mà còn củng cố lại những từ đã biết. Hơn nữa, đọc mở rộng còn giúp người học nhớ được các chi tiết như ý nghĩa, chính tả và chức năng ngữ pháp của từ. Cuối cùng, bài báo đưa ra những gợi ý để có thể thực hiện được một chương trình đọc mở rộng hiệu quả, dựa trên ý kiến của nhiều tác giả khác nhau.

Tù khóa: học từ vựng, đọc mở rộng, học ngôn ngữ 


\section{APPENDIX}

Vocabulary Learning Form

\begin{tabular}{|l|l|l|l|l|}
\hline New word & Synonym & Definition & Original sentence & My sentence \\
\hline & & & & \\
\hline & & & & \\
\hline & & & & \\
\hline
\end{tabular}

